\title{
New Record of Brevipalpus Donnadieu (Acari: Tenuipalpidae) and Illustrated Key to Egyptian Species and Types
}

\author{
G. H. Rady ; A. M. Halawa ${ }^{* *}$; H. M. Abdelnabby ${ }^{*}$ and H. Zynhom \\ "Plant Protec. Dept.. l'ac, of $A$ gric.. Benha University. \\ ${ }^{* *}$ Fruit Acarology Dept., Plant Protec. Res. Institute. $\Lambda$ gric. Res. Center . Giza, Igypt.
}

\begin{abstract}
First record and re-description of Brevipalpus plucheae, Baker, Tuttle \& Abbatiello collected from the weed Com:dioscoridis $\mathrm{L}$. in citrus orchards. Illustrated key to the species and types of the genus Brevipalpus in Fgypt is provided.
\end{abstract}

Key words: Tenuipalpidae; Brevipalpus spp.

\section{INTRODUCTION}

The family Tenuipalpidae has a worldwide distribution with over 1100 valid species belonging to 38 genera. Most tenuipalpid species have been described from North America ( $33 \%$ of the total known flat mite fauna) and Africa (13\%), whereas little is known in the rest is known from other part of the world (Mesa et al. 2009). All tenuipalpid species are phytophagous and damage plants by directly feeding on epidermal cells of the stems, leaves and fruits. Several species are known to vector plant virus (Childers and Eerrick 2003; Kitajima et al. 2003; Rodrigues et al. 2003) and some species have been collected carrying fungal spores associated with plants (Evans et al. 1991, Ochoa et al. 1994). The majority of the species that cause economic damage to cultivated plants belongs to the two largest genera, Brevipalpus Donnadieu and Tenuipalpus Donnadieu. The first is a widespread genus included 282 species (Arabuli et al., 2015). Recently, new species of this genus have been described. In 2013, Brevipalpus incognitus Ferragut \&Navia was described in Brazil (Navia et al., 2013); while in 2014, Brevipalpus noranae Halawa \& Fawzy was described from Egypt(Navia et al., 2013; Halawa and Fawzy, 2014). Despite the high diversity of these mites in Egyptian agro-ecosystems, the genus Brevipalpus has been poorly studied whereas, several papers on mites of the family Tenuipalpidae were published by Sayed (1942, 1946, 1950), Attiah (1956), and Zaher (1984). Sayed (1942, 1946, 1950) and Attiah (1956) reported seven species in Egyptian fauna that were: $B$. lanceolatisetae Attiah, B. geisenheyneri Ruebsaamen, $B$. obovatus Donnadieu, $B$. phoenicis Geijskes, B. californicus (Banks), B. olearius Sayed, and B. lewisi McGregor. However, Zaher (1984) recorded only six species, four of them belonging to the genus Brevipalpus: B. obovatus, B. phoenicis, $B$. californicus, and $B$. olearius; while the other two species were placed in the genus Cenopalpus: $C$. lanceolatisetae Attiah and C. spinosus (Donnadieu) (= T. geisenheyneri Ruebsaamen). Recently, one species: Brevipalpus noranae Halawa \&Fawzy, 2014 was described as a new species and added to the Egyptian fauna. In this paper, Brevipalpus plucherk? Baker, Tuttle \& Abbatiello was re-rediscriiped an: illustrated for the first time in Egypt and provide an illustrated key to the recorded Egyptian species.

\section{MATERIALS AND METHODS}

A survey was conducted in fruit orchards and neighboring plants throughout six provinces of Egypt (Qalubia, Giza, Menufia, Behera, Dakahlia, Sohage). At each locality, sampling was carried out bi-weekly from October 2012 to September 2014. The samples included plant foliages, fruits, buds, branches, and grass individually bagged in tightly-closed plastic bags and transported on the same day to the Fruit Acarology Department, Plant Protection Research Institute, Agricultural Research Center. The elevation and longitude/latitude were recorded for each locality using a hand-held Garmin Global Positioning Device (GPS). Mites were removed using a fine hair brush under dissection stereo-microscope, then preserved in $70 \%$ ethanol. Selected mites were cleared in Nesbitt solution for 10-12minutes. Subsequently, mites were mounted on micro-slides in Hoyer's medium, and then dried at $40{ }^{\circ} \mathrm{C}$ for one week (Zhang 2003). The terminology used in the key follows Linquist (1985) and Mesa et al. (2009). The measurements are given in micrometers $(\mu \mathrm{m})$. The type material was deposited as slide-mounted specimens in the mite collection of the Agriculture Research Center, Plant Protection Research Institute, Fruit Acarology Department, Dokki, Egypt (ARC-PPRI).

\section{RESULTS AND DISCUSSION}

\author{
Family Tenuipalpidae Berlese \\ Subfamily Brevipalpinae Mitrofanov, 1973 \\ Ge nus Brevipalpus Donnadie u, 1875 \\ Brevipalpus plucheae, Baker, Tuttle \& Abbatiello, \\ 1975. (Figs. 1\&2) \\ Re-description: Female (holotype). Dorsal idiosoma
} (Fig. 1A) (excluding rostrum) 290 long (280-290 in 5 paratypes) and 155 wide (145-160). Rostrum barely 


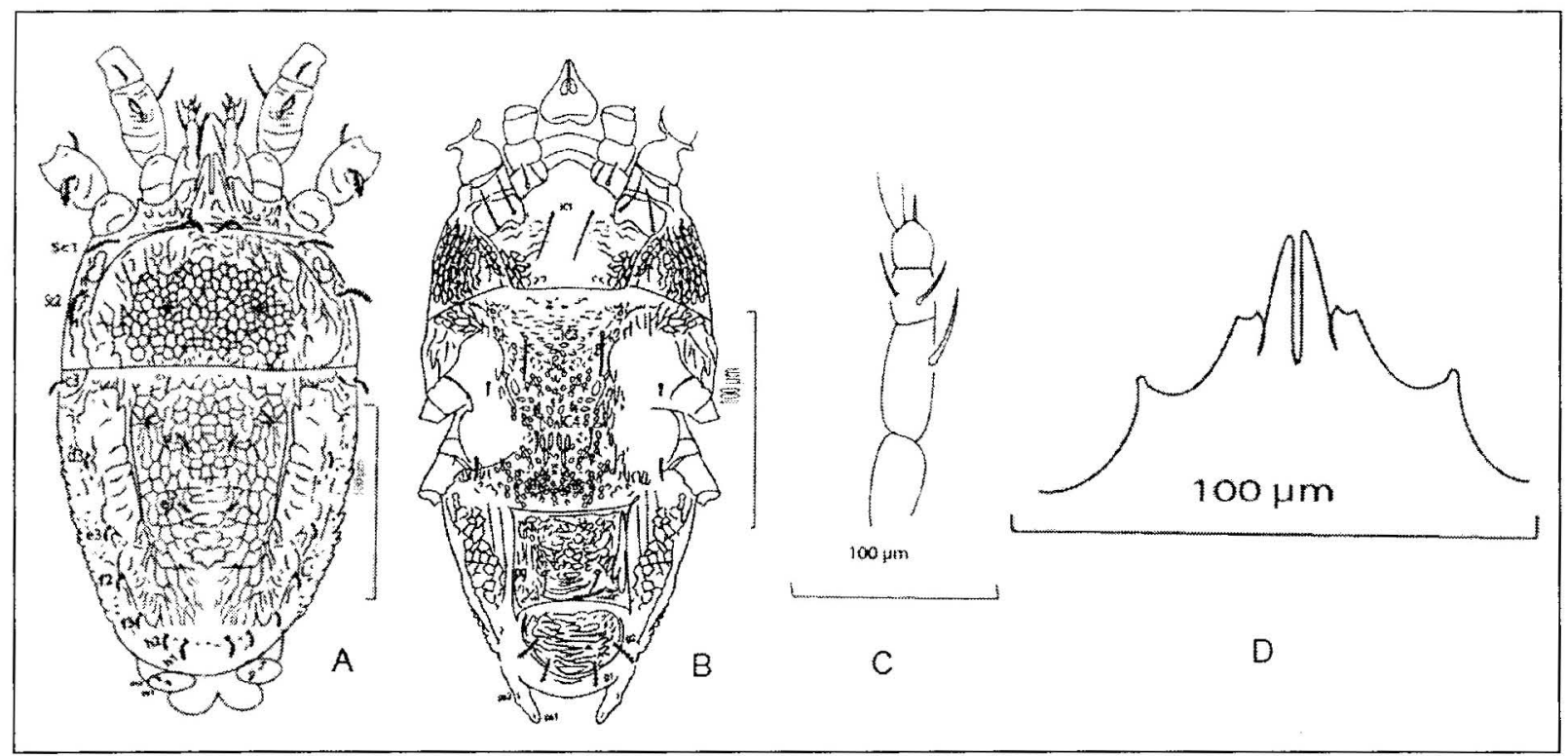

Fig.(1): Brevipalpus plucheae Baker, Tuttle \& Abbatiello, female. A. Dorsal idiosoma. B. Ventral idiosoma. C. Palpus, D. Rostral shield.

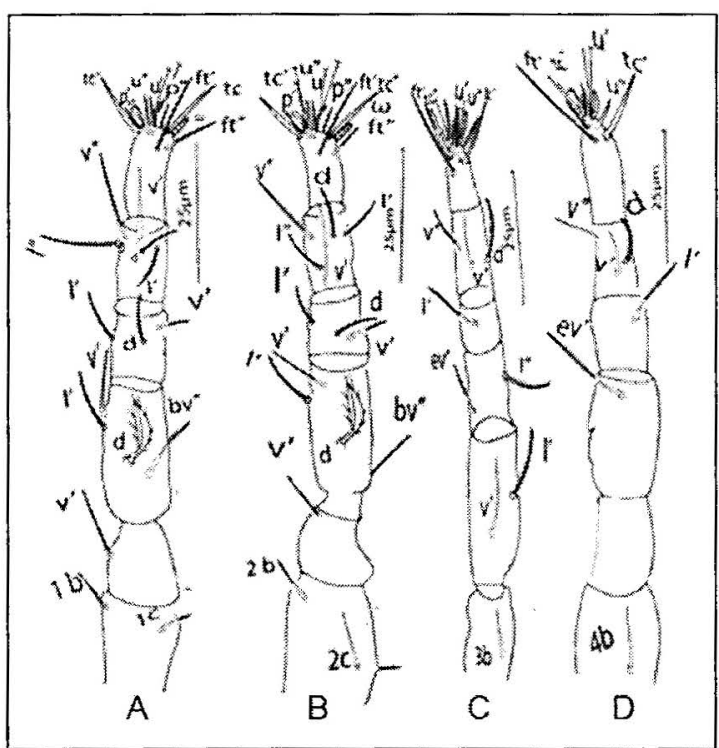

Fig.(2): Brevipalpus plucheae Baker, Tuttle \& Abbatiello, adult female. A. Leg I; B. Leg II; C. Leg III; D. Leg IV.

extending to middle of femur I. Rostral shield deeply cleft medially with stout, tapered median and dentate ancillary lobes on each side (Fig. 1D). Palps 4 segmented, terminal segment with 3 setae on distal segment ( 1 solenidion and 2 simple setae) (Fig. IC). Prodorsum with areolate dorsocentral and dorsolateral areas, strongly rugose lateral areas; poes present. Propodosoma with 3 pairs of lanceolate setae; lengths: v2 12 (9-16), scl 16 (13-17), and sc2 18 (15-18). Eyes 2 pairs, 1 pair on each side (Fig. 1A). Hysterosomal dorsum areolat -rugose with rugos dorsocentral area posterior to $c 2$ setae and strongly rugose lateral area; longitudinal dorsolateral furrows becoming obscure posteriorly; distinct

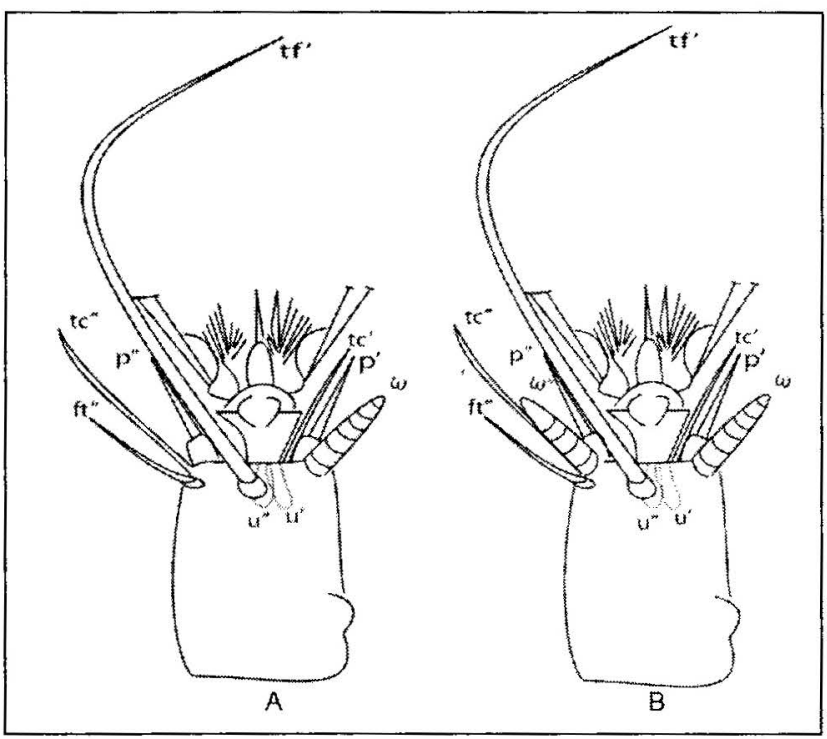

Fig. (3): Semi-schematic line drawing of leg II tarsus, A. Brevipalpus obovatus Donnadieu; Brevipalpus phoenicis (Gejjskes).

rugose lateral groves; pores present. Dorsocentral hysterosoma with 3 pairs of narrowly lanceolate setae; length of setae $\mathrm{c} 1$ and $d 17$ (6-9), el 8 (7-8). Seven pairs of slightly lanceolate dorsolateral opisthosomal setae shorter than distance between their bases; lengths: $c 311$ (11-12), d3 9 (9-11), e3 and $f 27$ (6-9), f3 and $h 28$ (6-8), hl 7 (5-7) (Figs.1\&2).Venteral idiosoma, the pregenital plate with sides uneven, barely perceptibly widening posteriorly, areolate- rugose; genital flap rugose to subimbricate- rugose; genital setae slender, slightly longer than pregenitals, paired laterally; area posterior to IC4 and intercoxal setal area pebbly areolate (FiglB). All ventral setae smooth; lengths of 
setae: ICI 21 (19-21), IC3 $17(15-17), \quad I C^{\prime}+13$ (11-14), pg $11(9-13), g 110(8-11), g 214$ (14-16). ps 16 (4-6), ps2 7 (7-7) (Fig. 1B). Leg segments wrinkled: number of setae on leg segments as follows: coxae 2-2-1-1, trochanters 1-1-2-1, femora 4-4-2-1, genua 3-3-1-1, tibiae 5-5-3-3, tarsi $8(\omega)-8(\omega)-5-5$. Dorsal setae of femora I and II leaf like lanceolate serrate. Tarsi I and II with I sensory rods each; leg chaetotaxy as follows: coxae I-II $b, c$; co.III-IV $b$; trochanters I, II, IV v'; tr. III I', $v^{\prime}$; femora $\mathrm{I}-\mathrm{II}, d, v^{\prime}, b v^{\prime \prime}, l^{\prime}$; fe. III $e v^{\prime \prime}, l^{\prime \prime}$; fe.IV $e v^{\prime}$; genua I-II l', $d, v^{\prime \prime}$; ge. III-IV l'; tibia I-II $d, l^{\prime}-l^{\prime \prime}, v^{\prime}-v^{\prime \prime}$; ti III-IV $d, v^{\prime}-v^{\prime \prime}$; tarsus I-II $u^{\prime}-u^{\prime \prime}$, $p^{\prime}-p^{\prime}, t c^{\prime}-t c^{\prime \prime}, f t^{\prime}-f t^{\prime \prime}, \omega ;$ ta. III-IV $u^{\prime}-u^{\prime \prime}, t c^{\prime}-t c^{\prime \prime}$, $f i$ (Fig. 2 A. b C.d).

Male: Not known.

Type material: Holotype female and 5 paratype females, ex Conyza dioscoridis L. (Asteraceae) in citrus farm: Giza province, $30 \circ 02^{\prime} 6^{\prime \prime} \mathrm{N}$. 31०12'18"E, 20 September 2014, coll. Hassan zynhom.

Type de positions: Holotype and 5 paratype females deposited at Plant Protection Research InstituteAgricultural Research Center - Fruit Acarolog: Department, Dokki, Cairo, Egypt.

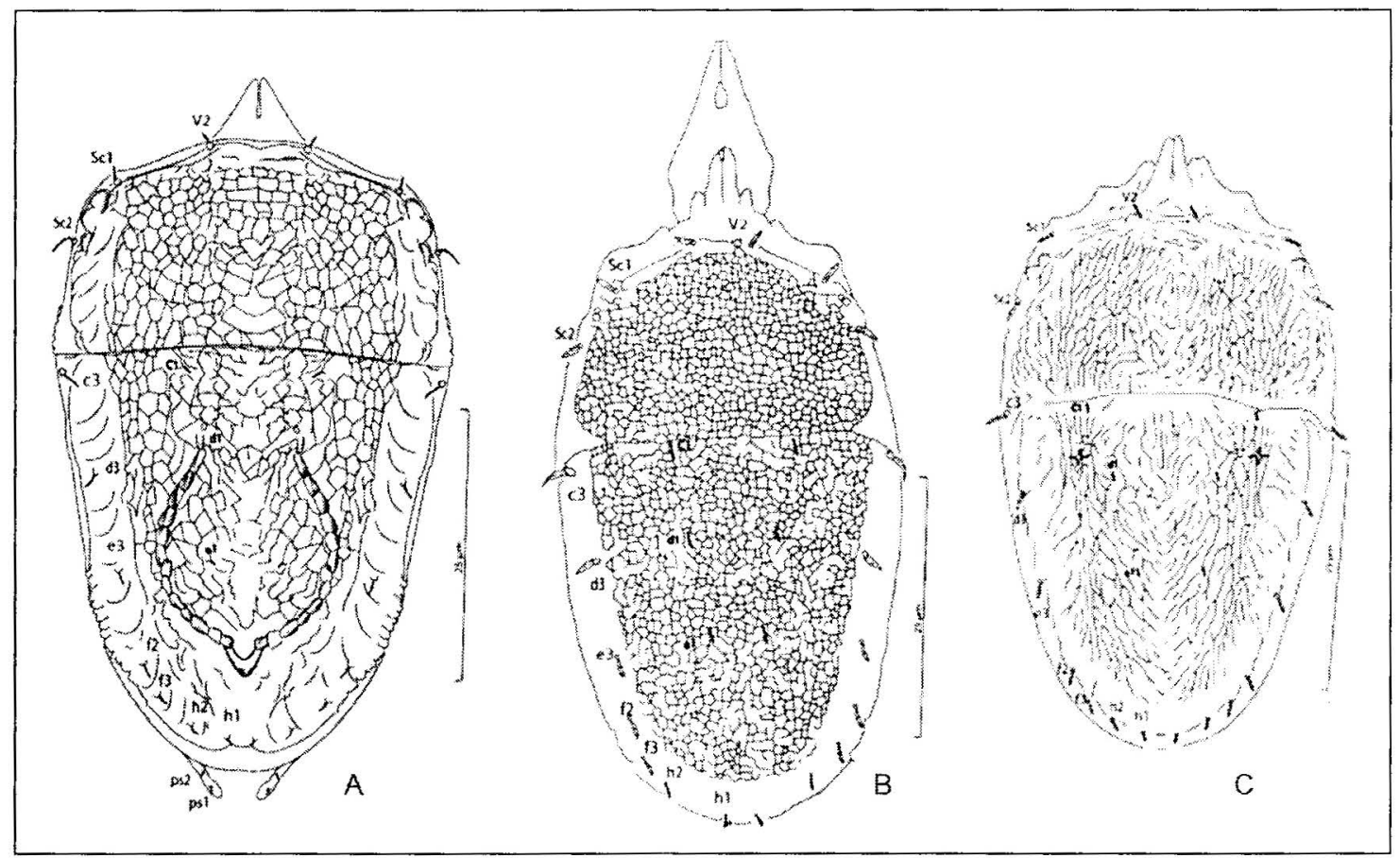

Fig.(4): Dorsal idiosoma, A. Brevipalpusnoranae Halawa \&Fawzy; B. Brevipalpus olearius Sayed after Zaher (1984), C. Brevipalpus lewisi McGregor after Attiah (1956).

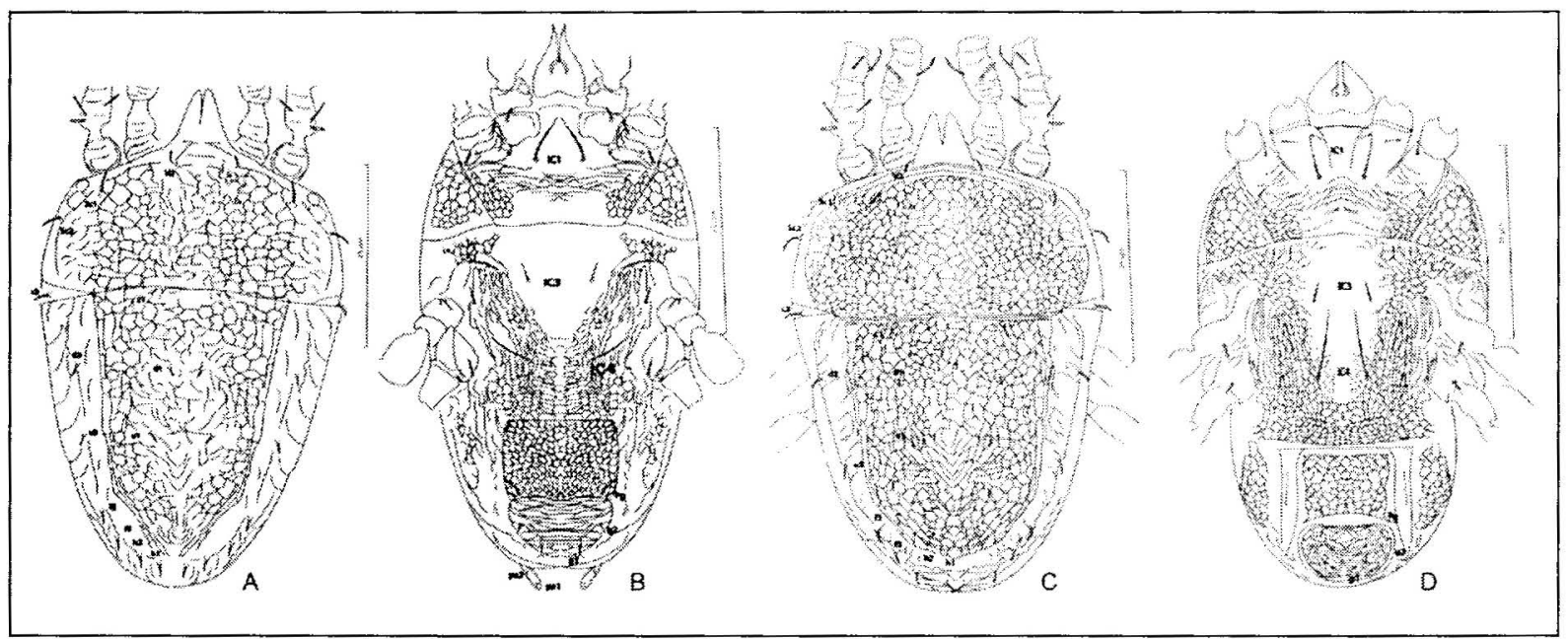

Fig. (5): Types of Brevipalpus californicus (Banks): A, Dorsal idiosoma of Type1.B, Ventral idiosoma of Type 1. C, Dorsal idiosoma of Type2.D. Ventral idiosoma of Type 1. 
Key to the Egyptian species of Brevipalpus in Egypt

Females

1. Hysterosoma with 6 pairs of dorso-lateral setae .... .

- Hysterosoma with 7 pairs of dorso-lateral setae. ........................................ 3

2. Tarsus II with 1 solenidion ........................ obovatus Donnadieu (Fig.3A)

- Tarsus II with 2 solenidi phoenicis (Geijskes) (Fig.3B)

3. Tarsus II with 1 solenidion. ............... 4

- Tarsus II with 2 solenidia; propodosoma with irregular striae medio-dorsally, reticulated elements occur medio-laterally .............. B. californicus (Banks) ...........................5

4. Hysterosomal dorsum with large vase (urn) shaped pattern, with small v-shaped extension posteriorly ....................... B. noranae Halawa \&Fawzy (Fig. 4A)

- Hysterosomal dorsum without vase shape pattern

. Propodosoma cuticle smooth to wrinkled (rugose) centrally with large closed cells laterally, forming reticulation; dorsal opisthosoma with cuticle between $\mathrm{c} 1-\mathrm{c} 1$ and e1-elsmooth wrinkled; cuticle posterior el-elwith few short, diagonal lines to weak $\mathrm{V}$-shaped folds ................. B. californicus (Banks) type 1 (Figs.5A\& B)

- Prodorsum cuticle entirely reticulate with weaker and faint reticulation centrally, but cells usually closed, some cells fused to form larger irregular cells; cuticle between cl-cl and dl-dl with weak reticulation wrinkled; dorsal opisthosoma with cuticle between $\mathrm{d} 1$-dland el-elwrinkled to irregularly folded; cuticle posterior el-el irregularly folded with few short transverse folds (V-shaped) .................................. californicus (Banks) type 2 (Figs.5C\& D)

6. Rostrum elongate, extending to the distal end of genu I; reticulate pattern covers almost entire surface of propodosoma and hysterosoma B. olearius Sayed(Fig.4B)

- Rrostrum not elongate, extending to middle of femur I

\section{.7}

7- Propodosoma with rugose dorsocentral area, subareolate- rugose dorsolateral and rugose lateral area ........ B. lewisi McGregor (Fig. 4C)

- Propodosoma with areolate dorsocentral and dorsolateral area, strongly rugose lateral area ...B. plucheae Baker, Tuttle \& Abbatiello (Figs.1 \& 2)

Brevipalpus obovatus Donnadieu, 1875 (Fig. 3A) Brevipalpus obovatus Donnadieu, 1875:144; Pritchard and Baker 1958: 231; Meyer and Ryke 1959:319.

Brevipalpus preger Donnadieu, 1875: 117.
Brevipalpus amicus Chaudhri. 1972: 65

Brevipalpus origunum Baker. Tuttle and Abbatiello. 1975: 18.

Brevipalpus assamensis Sadana and Gupta, 1983: 1.

Tenuipalpus inomatus Banks, 1912: 97.

Tenuipalpus bioculatus McGregor, 1914: 354.

Tenuipalpus pseudocuneatus Blanchard, 1940: 11.

Mate rial examined: 12 females ex Citrus aurantium L (Rutaceae) Sohage, Shandawil regioncoll. Hassan Zynhom 15 August 2013; Giza province, 30॰02' $6^{\prime} \mathrm{N}$, $31 \circ 12^{\prime} 18^{\prime \prime} \mathrm{E}, 17$ July 2014 coll. Hassan Zynhom; Menufia province, El-Bagour $30^{\circ} 26^{\prime} 6^{\prime \prime} \mathrm{N}, 31^{\circ} 02^{\prime} 6^{\prime \prime} \mathrm{E}$, 25 September 2013, coll. Hassan Zynhom ; 5 females ex Pyrus communis L (Rosaceae), 4 females ex Plumeria acutifolia Poir (Apocynaceae): Menufia province, El-Bagour district, $30^{\circ} 28^{\prime} 30^{\prime \prime} \mathrm{N}, 30^{\circ} 58^{\prime} 30^{\prime \prime}$ E, 25 September 2013, coll. Hassan Zynhom.

Re mark: This species was re-described in Egypt by Attiah (1956) and Zaher (1984), and has been on Pyrus communis L., Citrus aurantium L.; Pelargonium zonalle Ait, Clerodendrum sp., Hibiscus rosa-sinensis L., Gerbera jamesonii Bolus, Mentha sp. and Rosa sp.

Type de positions: Holotype and paratypes deposited at Plant Protection Research Institute- Agricultural Research Center - Fruit Acarology Department, Dokki, Cairo, Egypt (ARC-PPRI).

Relation to host: The mites live on lower surface of leaves and fruits causing brown scars.

Brevipalpus phoenicis (Geijskes, 1939) (Fig. 3B) Tenuipalpus phoenicis Geijskes, 1939: 230. Brevipalpus phoenicis, Sayed 1946: 360; Baker 1949: 360.

Brevipalpus mcbridei Baker, 1949: 374.

Brevipalpus papayensis Baker, 1949: 375.

Brevipalpus yothersi Baker, 1949: 373.

Brevipalpus phoenicoides Gonzalez, 1975: 86.

Material examined: 9 females and 2 males ex Citrus spp. (Rutaceae), 2 females ex Psidium guajava $\mathrm{L}$. (Myrtaceae), Sohage, Shandawil region, 20 july 2014, coll. Hassan Zynhom: Giza province, $30^{\circ} 02^{\prime} 6^{\prime} \mathrm{N}, 31^{\circ} 12^{\prime} 18^{\prime \prime} \mathrm{E}, 15$ June 2014 coll. Hassan Zynhom; 3 females ex Pyrus communis L. (Rosaceae): Qalubia province, Toukh cistrict, 3०21'18"N, 31०13'30"E, coll. Hassan Zynhom. 6 females ex Pyrus communis L. (Rosaceae) Egypt: Behera province, Behera, 30॰36'54"N, 30॰41'6"E, 28 June 2014, coll. Hassan Zynhom.

Re mark: The holotype of Brevipalpus phoenicis was collected from Phoenix sp. (Arecaceae) in the 
Netherlands. The Egyptian specimens were reported and described by Sayed (1946), Attiah (1956). and Zaher (1984). Our study completely agrees with the description of B. phoenicis given by Gejjskes (1939) and Halawa \& Fazy (2014).

Type de positions: Holotype and paratypes deposited at Plant Protection Research Institute- Agricultural Research Center - Fruit Acarology Department, Dokki, Cairo, Egypt.

Relation to host: The mites live on lower surface of leaves and fruits causing brown scars.

Brevipalpus noranae Halawa \& Fawzy, 2014 (Fig. 4A).

No synonyms.

Type material: Holotype female and 3 paratype females, Citrus aurantium L. (Rutaceae) as mixed plantations: Qalyubia province, Tukh district, Moshtohor village, $30^{\circ} 21^{\prime} 18^{\prime \prime} \mathrm{N}, 31^{\circ} 13^{\prime} 30^{\prime \prime} \mathrm{E}, 20$ July 2014, coll. Hassan Zynhom.

Remark: The holotype of Brevipalpus noranae was collected on Citrus aurantium L. (Rutaceae) and Malus domestica Borkh (Rosaceae) and described by Halawa \& Fawzy (2014). Our study completely agrees with the description of $B$. noranae given by Halawa \& Fazy (2014).

Type depositions: Holotype and 4 paratype females deposited at Plant Protection Research InstituteAgricultural Research Center - Fruit Acarology Department, Dokki, Cairo, Egypt .

Relation to host: The mites live on lower surface of leaves and fruits causing brown scars.

\section{Brevipalpus olearius Sayed, 1950 (Fig. 4B).}

Material examine d: 4 females ex Olea europea L.( Oleaceae) Menufia province, El-Bagour30 $26^{\prime} 6^{\prime \prime} \mathrm{N}$, $31 \circ 02^{\prime} 6 " \mathrm{E}, 20$ july 2014, coll. Hassan Zynhom: Qalubia province; 3 females ex Olea europea L.( Oleaceae) Egypt: Giza province, Dokki, 30॰02' ${ }^{\prime \prime} \mathrm{N}$, 31०13'30"E, 28 Dec. 2012.

Remark: The flat mite Brevipalpus olearius was found on Olea europea L. in Egypt by Sayed (1950). Specimens collected in this study were compared with the holotype deposited at Plant Protection Research Institute, Agricultural Research Center, Egypt.

Type depositions.Holotype and 4 paratype females deposited at Plant Protection Research InstituteAgricultural Research Center - Fruit Acarology
Department. Dokki. Cairo, Egypt (ARC-PPRI).

Relation to host. The mites live on lower surface of leaves.

Brevipalpus lewisi McGregor, 1949 (Fig. 4C).

No synonyms.

Material examined: 3 females and one male ex Citrus spp. (Rutaceae): Menufia province, ElBagour $30^{\circ} 26^{\prime} 6^{\prime} \mathrm{N}, \quad 31^{\circ} 02^{\prime} 6^{\prime \prime} \mathrm{E}, 25$ August, coll. Hassan Zynhom.

Remark: In Egypt, this species was described by Attiah (1956), from specimens collected at ElBagour, Menufia. Since then this species was not recorded again in Egypt until 2014 when recorded again by Halawa and Fawzy were recorded again on the same host plant and at the same place. During our study this species was recorded in the same place and on same host plant. Specimens collected in this study were compared with the holotype deposited at Plant Protection Research Institute, Agricultural Research Center, Egypt.

Type depositions: Holotype and 2 paratype females deposited at Plant Protection Research InstituteAgricultural Research Center - Fruit Acarology Department, Dokki, Cairo, Egypt.

Relation to host:The mites live on lower surface of leaves and fruits causing brown scars.

Brevipalpus californicus (Banks, 1904)(Fig.4)

Tenuipalpus californicus Banks, 1904: 55.

Tenuipalpus australis Tucker, 1926: 3.

Tenuipalpus vitis Womersley, 1940: 241.

Brevipalpus confusus Baker, 1949: 380.

Brevipalpus browningi Baker, 1949: 382.

Brevipalpus woglumi McGregor, 1949: 19.

Brevipalpus californicus, Pritchard and Baker 1951:

30; Meyer and Ryke 1959:319.

Type 1 (Fig. 4 A \& B).

Material examined: 7 females and Imales ex Citrus spp. (Rutaceae), 5 females ex Psidium guajava L. (Myrtaceae): Qalubia province, El- Marg, $30^{\circ} 21^{\prime} 18^{\prime \prime} \mathrm{N}, \quad 31^{\circ} 13^{\prime} 30^{\prime \prime E}, 20$ July 2014, Citrus aurantium L (Rutaceae): Giza province, Nikla village, 30 $02^{\prime} 6^{\prime \prime} \mathrm{N}, 31^{\circ} 12^{\prime} 18^{\prime \prime} \mathrm{E}, 25$ August 2014.

Remark:. Type 1 of Brevipalpus californicus (Banks) was recorded and described for first time in USA by Ochoa et al. (2013); while the same type was recorded and described in Egypt for first time by Halawa et al.(2013). Our study agrees with description this type by the mentioned authored. 
Type de positions: Holotype and 2 paratype females deposited at Plant Protection Research InstituteAgricultural Research Center - Fruit Acarology Department, Dokki, Cairo, Egypt.

Relation to host: The mites live on lower surface of leaves and fruits causing brown scars.

Type 2 (Fig. 4C \& D).

Material examined:5 females ex Citrus spp. (Rutaceae); Menufia province, El-Bagour $30^{\circ} 26^{\prime} 6^{\prime \prime} \mathrm{N}$, 31.02'6"E, 20 july 2014, 5 females ex Pyrus communis L. (Rosaceae): Behera province, Behera, $30^{\prime} 366^{\prime} 4^{\prime \prime N}, 30^{\circ} 41^{\prime} 6^{\prime \prime E}, 25$ August 2014, 3 females ex Citrus spp. (Rutaceae): Dakahlia province, Tonamel village, $30^{\circ} 50^{\prime} 6^{\prime \prime} \mathrm{N}, 31^{\circ} 15^{\prime} 18^{\prime \prime} \mathrm{E}$.

Re mark: Type 2 of Brevipalpuscalifornicus (Banks) was recorded and described for first time in USA by Ochoa et al. (2013); while the same type was recorded and described in Egypt for first time by Halawa et al. (2013). Our study agrees with description this type by the mentioned authored.

Type depositions: Holotype and 2 paratype females deposited at Plant Protection Research InstituteAgricultural Research Center - Fruit Acarology Department, Dokki, Cairo, Egypt.

Relation to host: The mites live on lower surface of leaves and fruits causing brown scars.

\section{ACKNOWLEDGMENTS}

Authors express their deep gratitude to Dr. Ron Ochoa and Greg Evans (University of Florida Department of Entomology, USA) for confirmation of Brevipalpus plucheae species.

\section{REFERENCES}

Arabuli, T.; Conaboglu, S. and Kvavadze, E. 2015. New records of tenuipalpid mites (Acari: Tenuipalpidae) for the Georgian and Caucasus fauna. Turkish Journal of Zoology, 39: 335-337.

Attiah, H. 1956. The genus Brevipalpus in Egypt. Bulletin of the Entomological Society of Egypt, 40: 433- 448.

Baker, E.W. 1949. The genus Brevipalpus (Acarina: Pseudoleptidae). The American Midland Naturalist, 42 (2): 350-402.

Baker, E. W.; Tuttle, D. M. and Abbatiello, M. J. 1875. The false spider mites of Northwestern and Northcentral Mexico (Acrina: Tenuipalpidae). Smithgsn. Contrib. Zool., 194:1-23.

Blanchard, E. E. 1940. Tres ácaros dañinos para los cultivos argentinos. Revista de la Facultad de ronomía , 24: 11-18.
Banks, N. 1904. Four new species of injurious mites. Journal of the New York Entomological Society, 12: $53-56$.

Banks, N. 1912. New American mites. Proceedings of the Entomological Society of Washington, 14: 96-102.

Chaudhri, W. M. 1972. Description of five new species of Temuipalpus (Acarina: Tenuipalpidae) from Pakistan. Sind University Research Journal, 6(1):17-29.

Childers,C. C. and Erric K. S. 2003. Brevipalpus mites as vectors of unassigned rhabdoviruses in various crops. Exp. Appl. Acarol., 30:1-3.

Donnadieu, A. L. 1875. Recherches pour servir a l'histoire des Tétranyques. Thèses Faculté des Sciences de Lyon - Francea, 1- 131.

Evans, A. C.; Marrett, S.; Torrescorzo, J.; Ku, S. and Collins, L. 1991. MRI-PET correlation in three dimensions using a volume-of-interest (VOI) atlas. Journal of Cerebral Blood Flow and Metabolism, 11(2):69-78.

Geijskes, D. C. 1939. Beitäge zur kenntnis der europäischen spinnmilben (Acari:Tetranychoidea), mit bensonderer berücktigung der Niederländischen arten. Mededeelingen van de Landbouwboogeschool Wageningen, 42: 1-68.

González, R. H. 1975. Revision of the Brevipalpus phoenicis "complex" with descriptions of new species from Chile and Thailand (Acarina: Tenuipalpidae). Acarologia, 17(1): 81-91.

Halawa A. M. and Fawzy, M. 2014. A new species of Brevipalpus Donnadieu (Acari: Tenuipalpidae) and key to the Egyptian species. Zootaxa, 3755: 87-95.

Halawa, A. M.; Abdallah A. A. and Ebrahim, A. A. 2013. Types of Brevipalpus californicus (Banks) (Acari: Tenuipalpidae) in Egypt. Acrines, 7(2): 13-16.

Kitajima, E. W.: Chagas, C. M. and Rodrigues, J. C. V. 2003. Brevipalpus-transmitted plant virus and virus-like diseases: cytopathology and reports of some recent cases. Exp. Appl. Acarol., 30:135160.

Mesa, N. C.; Ochoa, R.; Welbourn, W.; Calvin Evans, G. A. and Moraes, G. J. 2009. A catalogue of the Tenuipalpidae (Acari) of the world with a key to the genera. Zootaxa, 2098: 1-185.

Meyer, M. K. P. S. and Ryke, P. A. J. 1959. South Africa plant parasitic mites of the families Tenuipalpidae and Tuckerellidae (Acarina : Prostigmata). Journal of Entomological Society of Africa, 22 (2): 316-329.

McGregor, E. A. 1914. Four new tetranychids. Annals of the Entomological Society of America, 7: 354-365.

McGregor, E. A. 1949. Nearctic mites of the family Pseudoleptidae. Memoir of the Southern California Academy of Sciences, 3 (2): 1--45. 
Mitrofanov, V. I. 1973. Revision of the system of phytophagous mites of the subfamily Brevipalpinae (Trombidiformes, Tenuipalpidae). Zoologichesky Zhurnal, 52 (4): 507-511.

Navia, D.; Mendonca, R. S.; Ferragut, F.; Miranda. L. C.; Trincado, C.; Michaux, J. and Navajas, M. 2013. Cryptic diversity in Brevipalpus mites (Tenuipalpidae). Zool. Scr., 42: 406-426.

Ochoa, R.; Aguilar, H. and Vargas, C. 1994. Phytophagous mites of Central America: an illustrated guide. CATIE, Serie tecnica, manual tecnico no. 6 English ed, p 234.

Ochoa, R.; Beard, J.; Bauchan, G.; Matthew, T.; Redford, A.; Walters, T. and Mitter, C. 2013. Flat mites of the world. http://idtools.org/id/mites/flatmites

Pritchard, A. E. and Baker, E. W. 1958. The false spider mites (Acarina: Tenuipalpidae). University of California Publications Entomology, 14: 175-274.

Rodriguez, J. C. V.; Kitajima, E.W.; Childers C.C. and Chagas, C. M. 2003. Citrus leprosis virus vectored by Brevipalpus phoenicis (Acari: Tenuipalpidae) on citrus in Brazil. Exp. Appl. Acarol., 30:161-179.

Sadana, G. L. and Gupta, B. K. 1983. Phytophagous mite fauna of Assan together with new records and new species. Entomon, 8(1): 1-6.
Saved. M.T. 1942. Contribution to the knowledge of Acarina of Egypt. II-The genus Tenuipalpus Donnadieu. Bulletin Society of Fouadler Entomology. 26: 93-113.

Sayed. M.T. 1946. Description of Tenuipulpus granati nov. spec. and Brevipalpus pyri nov. spec. Bulletin Society of Fouadler Entomology, 30: 98104.

Sayed, M.T. 1950. Description of a new genus and two new species of the family Tenuipalpidae. Proceedings of the 8th International Congress of Entomology, 1018-1021.

Tucker, M. A. 1926. Some South African Mites. Mainly Tetranychidae and Eriophyidae. Union of South Africa Department of Agricuiture, Division of Entomology, Memoir No. V. Pretoria, 5: 3-15.

Womersley, H. 1940. Studies in Australian Acarina Tetranychidae and Trichadenidae. Transactions of the Royal Society of South Australia, 64 (2): 233265.

Zaher, M. A. 1984. Phytophagous mites in Egypt. PL.480 Programme U.S.A. Project No. EG-ARS30. Grant No. FG-EG, 228 pp.

Zhang, Z. Q. 2003. Mites of Greenhouses: Identification, Biology and Control. Centre of Agriculture and Biosciences International Publishing, Wallingford, United Kingdom, xii + $244 \mathrm{pp}$. 